\title{
PENGEMBANGAN BAHAN AJAR TAJWID DI SMP TAHFIDZ AL-AMIEN
}

\author{
Abdul Hamid Bakir \\ Dosen Program studi Pendidikan Agama Islam Fakultas Agama Islam \\ Universitas Muhammadiyan Jember \\ Email: abdulhamidbakir@unmuhjember.ac.id
}

\begin{abstract}
Subject Tajweed is the basic science to learn how to read the Qur'an in both good and true, is also a prerequisite for junior high students Tahfidz AlAmien before starting the program memorize the Quran. Realization of these goals require recitation of subjects learning resources that support the learning process. Based on the results of preliminary studies in the field through observation and interviews found that the majority of junior high school students in grade VII Tahfidz Al-Amien had difficulty in learning Tajweed with a variety of different reasons including: the difficulty distinguishing between a legal reading by reading other law, the difficulty in pronunciation hijaiyah letter and the application of the rules of tajweed in reading the Qur'an, and the lack of teaching materials used in the presentation of examples, explanations, and practice questions. Another problem lies in the learning process is emphasized only on the ability of students to memorize rules and examples without being to understand the concept of the examples and rules. So what happened next is when the learning activities students completed only good in theory but weak in application. One alternative to solve these problems is to design and develop instructional materials. The research objective of this development was to produce a package of teaching materials tajwid subjects designed and developed according to the characteristics and learning needs of junior high school students in grade VII Tahfidz Al-Amien. The model used in developing these materials is Dick \& Carey model. The reason for Dick \& Carey model is based on the premise that this model: 1) use a systems approach to complete the steps. 2) has four characteristics that should be owned in the development of learning, namely: refers to the goal, there is harmony with the objective, systematic, and based on the evaluation.
\end{abstract}

Keywords: Development, Teaching Materials, Dick \& Carey model

\section{PENDAHULUAN}

Al-Qur'an bagi umat Islam selain sebagai kitab suci, merupakan pedoman hidup dan sumber hukum dalam menjalani kehidupan di dunia. Sebagai pedoman hidup dan sumber hukum, tentunya diharapkan bagi segenap muslim untuk selalu melandaskan setiap tindakan atau perbuatannya berdasarkan Al-Qur'an. Untuk dapat mengetahui secara pasti tentang apa yang terkandung di dalamnya, 
setiap muslim dituntut untuk selalu membaca, mempelajari, dan menela'ah ayat-ayat yang tertulis di dalamnya. Hal ini bukanlah hal yang mudah karena untuk dapat memiliki kemampuan tersebut diperlukan kecakapan khusus dan waktu yang relatif lama untuk dapat mempelajari dan menguasai cara membacanya.

Sebagaimana kita maklumi, AlQur'an diturunkan kepada kaum muslim dalam bahasa Arab. Karena itu, bagi kita masyarakat Indonesia yang notabene berbahasa Indonesia dalam kehidupan sehari-hari, untuk dapat membacanya dengan baik dan benar diperlukan pengetahuan khusus dalam membaca tulisan Arab. Pengetahuan khusus yang harus dipelajari oleh kaum muslimin untuk dapat membacanya secara sempurna sesuai dengan kaidah yang berlaku dalam hukum membaca Al-Qur'an adalah ilmu Tajwid.

Ilmu Tajwid adalah ilmu yang dipergunakan untuk mengetahui tempat keluarnya huruf (makhorijul huruf), sifatsifat huruf, dan bacaan-bacaan Al-Qur'an (Misbahul Munir, 2005: 141). Secara umum, hukum mempelajari ilmu Tajwid adalah Fardlu Kifayah atau merupakan kewajiban kolektif. Artinya, mempelajari ilmu Tajwid secara mendalam tidak diharuskan bagi setiap kaum muslimin, tetapi cukup diwakili oleh beberapa orang saja. Adapun hukum membaca Al-Qur'an dengan menggunakan aturan Tajwid adalah Fardlu 'Ain atau merupakan kewajiban pribadi (Moh. Wahyudi, 2008: $6)$.

Untuk melaksanakan perintah agama di atas, dilaksanakanlah pembelajaran membaca Al-Qur'an. Dalam pelaksanaannya terdapat variasi-variasi.
Pembelajaran membaca Al-Qur'an yang diselenggarakan di surau-surau, mushalla, masjid, dan TPA (Taman Pendidikan AlQur'an) bagi pemula hanya fokus pada kemampuan membaca tulisan Al-Qur'an dan bentuk-bentuk huruf hijaiyah saja. Adapun pelaksanaan di lembaga-lembaga pendidikan Islam formal seperti Madrasah Ibtidaiyah (MI), Madrasah Diniyah (MD), pelajaran Tajwid merupakan kurikulum wajib yang harus diajarkan kepada para siswanya, lebih-lebih di kalangan pesantren, karena lembaga-lembaga pendidikan Islam tersebut memang secara khusus mengkaji tentang ilmu-ilmu keislaman, termasuk di dalamnya ilmu AlQur'an dan Tajwid sebagai bagian dari kajian ilmu Al-Qur'an.

Berdasarkan observasi awal yang dilaksanakan di SMP Tahfidz Al-Qur'an Al-Amien, sebagian besar siswa SMP Tahfidz Al-Qur'an Al-Amien mengatakan kesulitan dalam mempelajari pelajaran Tajwid. Alasan mereka kesulitan dalam mempelajari Tajwid adalah terletak pada bahan ajar, karena pada bahan ajar yang digunakan kurang banyak dalam menyajikan contoh bacaan, penjelasannya kurang, dan minim soal latihan. Sedangkan bahan ajar merupakan unsur inti yang ada dalam kegiatan belajar mengajar, karena bahan ajar itulah yang diharapkan dapat dikuasai oleh siswa. Fathurrohman dan Sutikno (2007:14) mengemukakan bahwa bahan ajar/materi ajar merupakan medium untuk mencapai tujuan pengajaran yang 'dikonsumsi' oleh peserta didik.

Di sisi lain, bahan ajar yang tersedia selama ini kurang menarik minat siswa untuk membaca, karena bahan ajar yang ada hanya berisikan materi-materi 
baku yang dikemas tanpa menggunakan sentuhan-sentuhan teknologi multimedia, khususnya multimedia interaktif. Kebanyakan bahan ajar yang tersedia hanya berisi materi-materi yang ditulis dengan teks tanpa disertai dengan polesan desain grafis dan variasi ilustrasi yang menarik.

\section{METODE PENELITIAN PENGEMBANGAN}

Dalam mengembangkan bahan ajar Tajwid, model pengembangan yang dipakai adalah model Dick, Carey \& Carey dengan beberapa penyesuaian. Model ini merupakan salah satu model rancangan pembelajaran yang berpendekatan sistem yang memandang bahwa pembelajaran adalah suatu himpunan dari bagian-bagian yang saling terhubung yang semuanya bekerja bersama-sama menuju tujuan yang telah ditetapkan. Agar sebuah pembelajaran dapat berjalan secara efektif, kontribusi setiap komponen harus ditetapkan, dinilai, dan direvisi untuk mencapai suatu hasil yang optimal. Maka efektifitas pendekatan ini terletak pada kecermatan dalam menganalisis komponen-komponen pembelajaran yang ada dalam sistem.

Beberapa pertimbangan yang melatarbelakangi penggunaan model Dick, Carey \& Carey adalah: 1) Model Dick \& Carey menggunakan pendekatan sistem dengan langkah-langkah yang lengkap dan dapat digunakan untuk pembelajaran secara klasikal atau individual. 2) Model Dick \& Carey memenuhi empat karakteristik yang harus dimiliki dalam pengembangan pembelajaran yaitu: a. mengacu pada tujuan, b. terdapat keserasian dengan tujuan, 3. sistematik, berpedoman pada evaluasi (Miarso, 1987). 3) Model Dick \& Carey bersifat prosedural dengan langkahlangkah yang jelas dan berurutan. 4) Model Dick \& Carey dapat digunakan untuk pengembangan bahan ajar pada peningkatan ranah informasi verbal, keterampilan intelektual, psikomotor, dan sikap. 5) Mata pelajaran Tajwid merupakan mata pelajaran yang bersifat berjenjang dan berurutan. Hal ini sesuai dengan salah satu karakteristik dari model Dick \& Carey.

Adapun langkah-langkah pengembangan model Dick \& Carey adalah sebagai berikut:

1. Mengidentifikasi tujuan pembelajaran umum. Tujuan pembelajaran umum merupaka pernyataan umum tentang hasil pengarahan yang diinginkan (Degeng, 1989). Sasaran tujuan ini mengacu pada keseluruhan isi bidang studi yang disampaikan dalam kegiatan pembelajaran.

2. Melakukan analisis pembelajaran. Langkah ini dimaksudkan untuk mengidentifikasi keterampilan yang dibutuhkan untuk mencapai tujuan umum. Di sini setiap rumusan tujuan umum dianalisis sesuai dengan karakteristik domain belajar, yaitu informasi verbal, keterampilan intelektual, keterampilan psikomotor, dan sikap.

3. Mengidentifikasi kemampuan awal dan karakteristik siswa. Langkah ini dimaksudkan untuk mengetahui kemampuan awal yang telah dimiliki oleh siswa dan keragaman karakter belajar mereka. Identifikasi kemampuan awal dan karakteristik 
belajar siswa bisa diperoleh melalui tes kompetensi dan pengamatan.

4. Merumuskan tujuan khusus pembelajaran. Langkah ini dimaksudkan untuk menetapkan tujuan khusus pembelajaran berdasarkan analisis tujuan umum dan pernyataan tentang kemampuan awal dan karakteristik peserta didik. Dick \& Carey (1990) menyatakan bahwa tujuan pembelajaran khusus merupakan uraian terperinci tentang apa yang dapat dilakukan siswa pada akhir kegiatan pembelajaran tertentu.

5. Mengembangkan perangkat penilaian. Langkah ini dimaksudkan untuk dapat mengembangkan butir-butir acuan penilaian. Kriteria penilaian adalah alat penilaian yang dirancang untuk mengukur unjuk kerja (performance) yang diharapkan dapat dicapai dalam tujuan khusus pembelajaran. Menurut Dick \& Carey (1990) terdapat 4 jenis tes acuan patokan yaitu:

a. Entry Behavior Test. Tes ini diterapkan dalam kegiatan pembelajaran dengan tujuan untuk mengukur keterampilan yang dimiliki siswa pada tingkat permulaan pembelajaran.

b. Pretest. Adalah tes acuan patokan yang berguna untuk mengenali profil pembelajaran sehubungan dengan analisis pembelajaran, dan bukan untuk menentukann perolehan nilai akhir.

c. Embeded Test. Adalah tes acuan patokan yang dilakukan dengan cara menyisipkan tes ke dalam bahan ajar. Tes ini dilaksanakan pada saat pembelajaran sedang berlangsung. d. Postest. Adalah tes acuan patokan yang mencakup seluruh tujuan pembelajaran. Tes ini dilaksanakan pada akhir pembelajaran. Tujuan dilaksanakannya postest adalah untuk mengidentifikasi bagianbagian dari pengajaran yang tidak berjalan.

6. Mengembangkan

Strategi

Pembelajaran. Strategi pembelajaran merupakan cara bagaimana pembelajaran disampaikan kepada siswa (Dick, Carey \& Carey, 2001). Hal ini senada dengan apa yang disampaikan oleh degeng bahwa strategi pembelajaran merupaka penataan cara-cara pembelajaran sehingga terwujud suatu urutan langkah prosedural yang dapat digunakan untuk mencapai hasil yang diinginkan (Degeng, 1997). Pada tahapan ini ada lima komponen yang harus diperhatikan yaitu:

a. Kegiatan pra-pembelajaran, seperti memberikan motivasi, memberikan informasi tentang keterampilan prasyarat, dan memberikan informasi tentang durasi waktu setiap pokok bahasan.

b. Penyajian informasi, yaitu menetapakan informasi, konsep, atauran atau prinsip yang perlu disampaikan kepada siswa.

c. Partisipasi peserta didik, yaitu menetapkan kegiatan apa yang bisa melibatkan partisipasi siswa dalam pembelajaran.

d. Tes dan penilaian

e. Kegiatan tindak lanjut

7. Mengembangkan dan memilih materi pembelajaran. Langkah ini 
dimaksudkan untuk menyeleksi dan menghasilkan materi pembelajaran. Pengembangan dan pemilihan bahan pembelajaran dilakukan berdasarkan tujuan pembelajaran. Pengembangan materi pembelajaran berdasarkan pada hasil kegiatan yang telah dilakukan pada beberapa tahapan sebelumnya.

8. Merancang dan melakukan evaluasi formatif. Penilaian formatif bertujuan untuk mengumpulkan data tentang efektifitas dan efisiensi produk yang telah dihasilkan. Data yang telah diperoleh kemudian digunakan sebagai patokan untuk melakukan revisi produk. Evaluasi formatif meliputi: 1) uji ahli, yakni ahli isi, ahli media, dan ahli desain, 2) uji perseorangan, 3) uji kelompok kecil, 4) uji kelompok besar.

9. Melakukan revisi pembelajaran. Pada tahapan ini, data yang telah diperoleh dari evaluasi formatif kemudian dianalisis dan diinterpretasikan untuk mengetahui permasalahan dan kesulitan yang dialami oleh siswa dalam mencapai tujuan pembelajaran. Data tersebut kemudian dijadikan acuan dalam merevisi produk yang telah dihasilkan sebelumnya.

\section{Gambar}

Langkah-langkah Pengembangan model Dick \& Carey

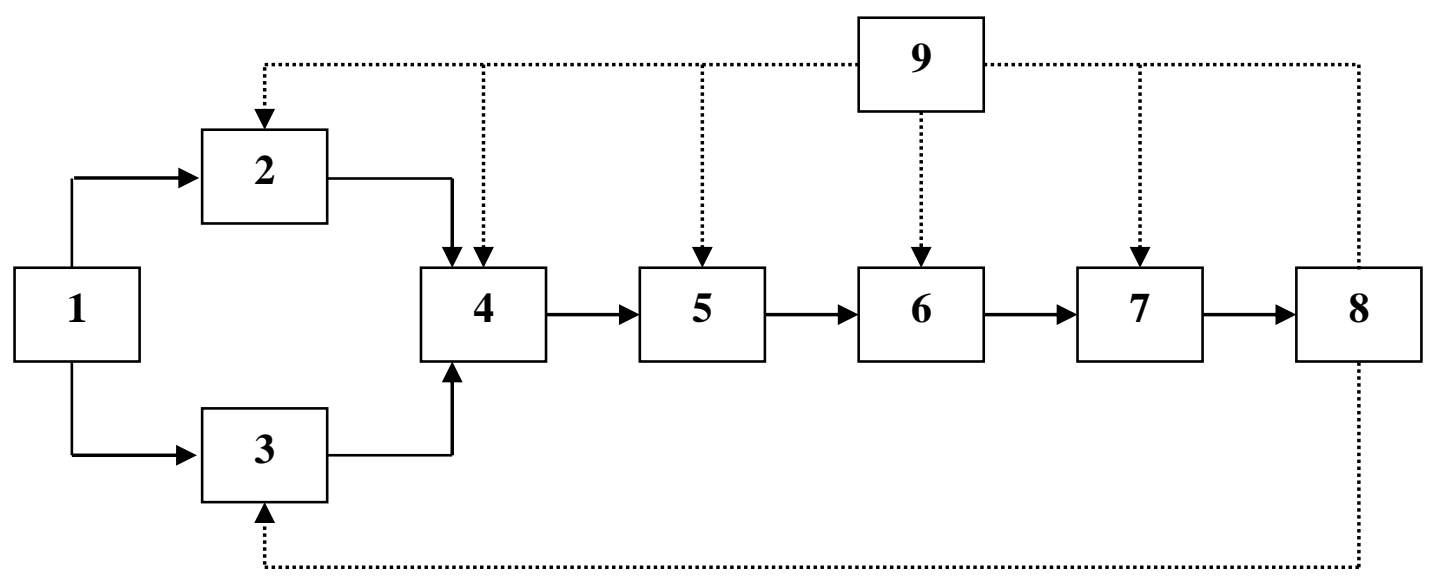

HASIL PENELITIAN DAN PEMBAHASAN

\section{Uji Ahli Isi/Materi Mata Pelajaran}

Produk pengembangan ini berupa bahan ajar Tajwid. Untuk validasi terhadap produk pengembangan ini, khususnya yang berkaitan dengan isi materi, pengembang percayakan kepada: K.H. Abdullah A. Zaini, Lc.Q., M.Th.I, merupakan ketua Guru Master (GM) AlQur'an wa Ulumuhu di Pondok Pesantren
Al-Amien Prenduan, dan pengurus Lembaga Pengembangan Tilawatil Qur'an (LPTQ) Kabupaten Sumenep. Beliau memperoleh gelar Lc.Q bidang Tafsir dan Qiraat (sab'ah dan 'asyaroh) dari Islamic University Madinah Munawwarah (IUM) pada tahun 1995, dan memperoleh gelar M.Th.I dari IAIN Sunan Ampel Surabaya pada tahun 2011. Saat ini beliau seringkali dipercaya untuk menjadi Juri dan pembimbing Musabaqah Tilawatil Qur'an (MTQ) dan Musabaqah Hifdhil Qur'an 
(MHQ) di tingkat regional maupun nasional.

Berdasarkan penilaian dari ahli isi/materi mata pelajaran, maka prosentase hasil penilaian/tanggapan ahli isi/materi terhadap bahan ajar Mata Pelajaran Tajwid adalah sebagai berikut:

1. Jumlah pilihan jawaban opsi 4 sebanyak 5 dari 23 item, maka perhitungannya adalah $5: 23 \times 100 \%=22 \%$

2. Jumlah pilihan jawaban opsi 5 sebanyak 18 dari 23 item, maka perhitungannya $18: 23 \times 100 \%=78 \%$
Berdasarkan hasil perhitungan secara keseluruhan, maka dapat diperoleh hasil bahwa ahli isi/materi memberikan jawaban mayoritas pada opsi jawaban nomor 5 (sangat memadai/sangat baik) yaitu sebanyak 18, maka perhitungannnya adalah $18: 23 \times 100 \%=78 \%$. Selanjutnya, jika hasil prosentase ini dicocokkan dengan tabel konversi perhitungan prosentase, maka hasil perhitungan tersebut dalam kategori BAIK, sehingga secara umum, isi atau materi bahan ajar Mata Pelajaran Tajwid tersebut layak digunakan dan tidak perlu direvisi.

Tabel

Konversi Tingkat Pencapaian dengan Skala 5

\begin{tabular}{|c|c|c|}
\hline Tingkat Pencapaian & Kualifikasi & Keterangan \\
\hline $90 \%-100 \%$ & Sangat Baik & Tidak perlu direvisi \\
\hline $75 \%-89 \%$ & Baik & Tidak perlu direvisi \\
\hline $65 \%-74 \%$ & Cukup & Perlu direvisi \\
\hline $55 \%-64 \%$ & Kurang & Perlu direvisi \\
\hline $0-54 \%$ & Sangat Kurang & Perlu direvisi \\
\hline
\end{tabular}

\section{Uji Ahli Desain}

Untuk validasi terhadap produk pengembangan ini, khususnya yang berkaitan dengan desain pembelajaran, pengembang percayakan kepada: Dr. H. Sulthon, M.Pd, beliau adalah seorang teknolog pembelajaran, konsultan pendidikan, direktur BPLP, dan juga dosen pascasarjana di Universitas Negeri Malang.

Berdasarkan penilaian dari ahli desain pembelajaran, maka prosentase hasil penilaian/tanggapan ahli desain pembelajaran adalah sebagai berikut:
1. Jumlah pilihan jawaban opsi 3 sebanyak 4 dari 37 item, maka perhitungannya adalah $4: 37 \times 100 \%=11 \%$

2. Jumlah pilihan jawaban opsi 4 sebanyak 28 dari 37 item, maka perhitungannya adalah $28: 37 \times 100 \%=75,5 \%$

3. Jumlah pilihan jawaban opsi 5 sebanyak 5 dari 37 item, maka perhitungannya adalah $5: 37 \times 100 \%=13,5 \%$

Berdasarkan hasil perhitungan secara keseluruhan, maka dapat diperoleh hasil bahwa ahli desain pembelajaran 
memberikan jawaban mayoritas pada opsi jawaban nomor 4 (memadai/baik) yaitu sebanyak 28, maka perhitungannnya adalah $28: 37 \times 100 \%=75,5 \%$. Selanjutnya, jika hasil prosentase ini dicocokkan dengan tabel konversi perhitungan prosentase, maka hasil perhitungan tersebut dalam kategori BAIK, sehingga secara umum, desain bahan ajar Mata Pelajaran Tajwid tersebut layak digunakan dan tidak perlu direvisi.

\section{Uji Ahli Media}

Untuk validasi terhadap produk pengembangan ini, khususnya yang berkaitan dengan media pembelajaran, pengembang percayakan kepada: Henry Praherdhiono, M.Pd, beliau adalah seorang teknolog pembelajaran, konsultan pendidikan, dan juga dosen Pascasarjana di Universitas Negeri Malang.

Berdasarkan penilaian dari ahli media pembelajaran, maka prosentase hasil penilaian/tanggapan ahli desain pembelajaran adalah sebagai berikut:

1. Jumlah pilihan jawaban opsi 4 sebanyak 7 dari 40 item, maka perhitungannya adalah

\section{$7: 40 \times 100 \%=17,5 \%$}

2. Jumlah pilihan jawaban opsi 5 sebanyak 33 dari 40 item, maka perhitungannya adalah

\section{$33: 40 \times 100 \%=82,5 \%$}

Berdasarkan hasil perhitungan secara keseluruhan, maka dapat diperoleh hasil bahwa ahli media pembelajaran memberikan jawaban mayoritas pada opsi jawaban nomor 5 (sangat memadai/sangat baik) yaitu sebanyak 33, maka perhitungannnya adalah $33: 40 \times 100 \%=82,5 \%$. Selanjutnya, jika hasil prosentase ini dicocokkan dengan tabel konversi perhitungan prosentase, maka hasil perhitungan tersebut dalam kategori BAIK, sehingga secara umum, bahan ajar sebagai media pembelajaran Mata Pelajaran Tajwid tersebut layak digunakan dan tidak perlu direvisi.

\section{Uji Coba Perorangan}

Hasil pengembangan berdasarkan masukan dari ahli isi/materi, ahli desain pembelajaran, dan ahli media pembelajaran, kemudian diuji cobakan pada 1 orang siswa yang bernama Syukron Maksudi kelas VII D berdasarkan masukan dari guru mata pelajaran Tajwid dan rekomendasi dari wali kelas. Adapun Prosedur uji coba perorangan sebagaimana berikut:

1. Pengembang berkonsultasi dengan guru mata pelajaran Tajwid untuk menentukan siswa yang dipilih sebagai subjek uji coba produk bahan ajar secara perorangan.

2. Guru mata pelajaran mengusulkan beberapa nama yang tidak begitu menonjol dalam mata pelajaran Tajwid.

3. Setelah mendapatkan beberapa nama berdasarkan usulan guru mata pelajaran, pengembang kemudian berkonsultasi dengan wali kelas masing-masing siswa.

4. Kemudian, dari beberapa nama tersebut muncul nama Syukron Maksudi kelas VII D.

5. Selanjutnya pengembang memberikan angket dan bahan ajar untuk dikaji, dianalisis dan diberikan komentar seperlunya.

Berdasarkan hasil dari uji coba perorangan, maka prosentase hasil 
penilaian/tanggapan perorangan adalah sebagai berikut:

1. Jumlah pilihan jawaban opsi 3 sebanyak 5 dari 20 item, maka perhitungannya adalah $5: 20 \times 100 \%=25 \%$

2. Jumlah pilihan jawaban opsi 4 sebanyak 15 dari 20 item, maka perhitungannya adalah

\section{$15: 20 \times 100 \%=75 \%$}

Berdasarkan hasil perhitungan secara keseluruhan, maka dapat diperoleh hasil bahwa uji coba perorangan memberikan jawaban mayoritas pada opsi jawaban nomor 4 (memadai/baik) yaitu sebanyak 15 , maka perhitungannya adalah $15: 20 \times 100 \%=75 \%$. Selanjutnya, jika hasil prosentase ini dicocokkan dengan tabel konversi perhitungan prosentase, maka hasil perhitungan tersebut dalam kategori BAIK, sehingga secara umum, produk bahan ajar mata pelajaran Tajwid layak digunakan dan tidak perlu direvisi.

\section{Uji Coba Kelompok Kecil}

Hasil pengembangan berdasarkan masukan dari responden, siswa kelas VII D sebagai subjek uji coba perorangan, kemudian diuji cobakan dalam kelompok kecil yang terdiri dari 4 orang siswa mewakili masing-masing kelas berdasarkan masukan dari guru mata pelajaran Tajwid dan rekomendasi dari wali kelas. Adapun Prosedur uji coba kelompok kecil sebagaimana berikut:

1. Pengembang berkonsultasi dengan guru mata pelajaran Tajwid untuk menentukan siswa-siswa yang dipilih sebagai subjek uji coba produk bahan ajar dalam kelompok kecil.

2. Guru mata pelajaran mengusulkan beberapa nama secara acak berdasarkan prestasi akademik, yaitu 2 orang siswa peringkat atas dan 2 orang siswa peringkat bawah.

3. Setelah mendapatkan beberapa nama berdasarkan usulan guru mata pelajaran, pengembang kemudian berkonsultasi dengan wali kelas masing-masing siswa.

4. Kemudian, pengembang menentukan pilihan responden masing-masing kelas diwakili oleh satu siswa mulai dari kelas VII A - VII D.

5. Berikutnya pengembang mengumpulkan siswa yang terpilih dan memberikan pengarahan bagaimana cara mengisi angket yang telah disediakan.

6. Selanjutnya pengembang memberikan angket dan bahan ajar untuk dikaji, dianalisis dan diberikan komentar seperlunya.

Berdasarkan hasil dari uji coba kelompok kecil, maka prosentase hasil penilaian/tanggapan kelompok kecil adalah sebagai berikut:

\section{a. Responden 1}

1. Jumlah pilihan jawaban opsi 4 sebanyak 15 dari 20 item, maka perhitungannya adalah $15: 20 \times 100 \%=75 \%$

2. Jumlah pilihan jawaban opsi 5 sebanyak 5 dari 20 item, maka perhitungannya adalah $5: 20 \times 100 \%=25 \%$

\section{b. Responden 2}

1. Jumlah pilihan jawaban opsi 4 sebanyak 5 dari 20 item, maka perhitungannya adalah $5: 20 \times 100 \%=25 \%$

2. Jumlah pilihan jawaban opsi 5 sebanyak 15 dari 20 item, maka 
perhitungannya adalah $15: 20 \times 100 \%=75 \%$

\section{c. Responden 3}

1. Jumlah pilihan jawaban opsi 3 sebanyak 1 dari 20 item, maka perhitungannya adalah $1: 20 \times 100 \%=5 \%$

2. Jumlah pilihan jawaban opsi 5 sebanyak 19 dari 20 item, maka perhitungannya adalah $19: 20 \times 100 \%=95 \%$

\section{d. Responden 4}

1. Jumlah pilihan jawaban opsi 4 sebanyak 4 dari 20 item, maka perhitungannya adalah $4: 20 \times 100 \%=20 \%$

2. Jumlah pilihan jawaban opsi 5 sebanyak 16 dari 20 item, maka perhitungannya adalah $16: 20 \times 100 \%=80 \%$

Berdasarkan hasil perhitungan secara keseluruhan, maka dapat diperoleh hasil bahwa uji coba kelompok kecil, sebagi berikut :

1. Responden $\mathbf{l}$ memberikan jawaban mayoritas pada opsi jawaban nomor 4 (memadai/baik) yaitu sebanyak 15, maka perhitungannya adalah $15: 20 \times 100 \%=75 \%$.

2. Responden 2 memberikan jawaban mayoritas pada opsi jawaban nomor 5 (sangat memadai/sangat baik) yaitu sebanyak 15, maka perhitungannya adalah $15: 20 \times 100 \%=75 \%$.

3. Responden 3 memberikan jawaban mayoritas pada opsi jawaban nomor 5 (sangat memadai/sangat baik) yaitu sebanyak 19, maka perhitungannya adalah 19:20x100\%=95\%.

4. Responden 4 memberikan jawaban mayoritas pada opsi jawaban nomor 5 (sangat memadai/sangat baik) yaitu sebanyak 16, maka perhitungannya adalah $\quad 16: 20 \times 100 \%=80 \%$. Selanjutnya, hasil rata-rata prosentase tanggapan responden adalah $75 \%+75 \%+95 \%+80 \%: 4=81,25 \%$.

Kemudian, hasil tersebut apabila dicocokkan dengan tabel konversi perhitungan prosentase, maka hasil perhitungan tersebut dalam kategori BAIK, sehingga secara umum, produk bahan ajar mata pelajaran Tajwid layak digunakan dan tidak perlu direvisi.

\section{Uji Coba Lapangan}

Berdasarkan saran dan masukan siswa dalam uji coba kelompok kecil selanjutnya selanjutnya diuji cobakan pada 26 siswa (uji coba lapangan). Siswa yang dijadikan responden uji coba lapangan adalah perwakilan dari masingmasing kelas. Setiap kelas diwakili oleh 5 orang siswa dengan klasifikasi prestasi akademik, 2 orang siswa pada peringkat atas, 1 orang siswa pada peringkat sedang/menengah, dan 2 orang siswa pada peringkat bawah. Hal ini dimaksudkan agar hasil uji coba nantinya benar-benar bisa mewakili masing-masing tingkat kemampuan intelektual di masing-masing kelas. Uji coba lapangan ini dilaksanakan oleh pengembang dan didampingi oleh guru mata pelajaran dan wali kelas. Adapun Prosedur uji coba lapangan sebagaimana berikut:

1. Pengembang berkonsultasi dengan guru mata pelajaran Tajwid untuk menentukan siswa yang dipilih sebagai subjek uji coba produk bahan ajar dalam kelompok kecil.

2. Guru mata pelajaran mengusulkan beberapa nama secara acak berdasarkan 
prestasi akademik, yaitu 2 orang siswa peringkat atas, 1 orang peringkat sedang/menengah dan 2 orang siswa peringkat bawah dari masing-masing kelas.

3. Setelah mendapatkan beberapa nama berdasarkan usulan guru mata pelajaran, pengembang kemudian berkonsultasi dengan wali kelas masing-masing siswa.

4. Berikutnya pengembang mengumpulkan siswa yang terpilih dan memberikan pengarahan bagaimana cara mengisi angket yang telah disediakan.

5. Selanjutnya pengembang memberikan angket dan bahan ajar untuk dikaji, dianalisis dan diberikan komentar seperlunya.

Berdasarkan hasil dari uji coba lapangan yang dilakukan terhadap responden/subjek uji coba sebanyak 20 siswa, maka prosentase hasil penilaian/tanggapan uji coba lapangan adalah $76.75 \%$, hasil tersebut diperoleh dari jumlah prosentase keseluruhan hasil tanggapan responden. Jika hasil tersebut dicocokkan dengan tabel konversi perhitungan prosentase, maka hasil perhitungan tersebut dalam kategori BAIK, sehingga secara umum, produk bahan ajar mata pelajaran Tajwid layak digunakan dan tidak perlu direvisi.

Data yang diperoleh dari hasil uji coba lapangan menunjukkan bahwa bahan ajar mata pelajaran Tajwid baik dari segi materi, desain pesan maupun desain teks, dan media yang dikembangkan dapat dikatakan sudah layak, baik, tepat, sesuai, memadai, dan menarik.

\section{KESIMPULAN}

Berdasarkan hasil uji coba yang telah dilakukan, keberadaan produk pengembangan mendapatkan respon yang positif dari siswa. Hal ini dapat dibuktikan dari hasil angket yang disebarkan kepada siswa pada saat uji coba lapangan. Sebesar $76.75 \%$ siswa menyatakan bahwa keberadaan produk pengembangan memudahkan dalam memahami mata pelajaran tajwid. Dengan demikian, dapat dikatakan bahwa produk pengembangan ini layak dipergunakan sebagai salah satu sumber belajar mata pelajaran tajwid bagi siswa kelas VII semester I SMP Tahfidz di Pondok Pesantren Al-Amien Prenduan Sumenep Madura.

Produk bahan ajar diperuntukkan siswa kelas VII SMP Tahfidz Al-Amien Prenduan, dan disesuaikan dengan karakteristiknya. Ini bukan berarti menutup kemungkinan untuk dipergunakan di kelas lain maupun di lembaga lain, akan tetapi perlu disesuaikan dengan kebutuhan dan karakteristik siswa setempat, hal ini diperlukan agar pencapaian hasil belajar yang diinginkan bisa maksimal

\section{DAFTAR PUSTAKA}

Al-Majidi, Abdussalam Muqbil. (2008). Bagaimana Rasulullah Mengajarkan Al-Qur'an Kepada Para Sahabat?, Terjemahan Muh. Hidayat. Jakarta: PT. Darul Falah.

Al-Qaththan, Syaikh Manna'. (2006). Mabahits $f i$ 'Ulumul Qur'an. Terjemahan Ainiur Rafiq ElMazni. Jakarta: Pustaka AlKautsar. 
Arsyad, Azhar. (2007). Media Pembelajaran, Jakarta: PT. Raja Grafindo Persada.

Degeng, I. N. S. (1989). Ilmu Pengajaran: Taksonomi Variabel, Jakarta: Depdikbud, Direktorat Jenderal Pendidikan Tinggi Proyek Pengembangan Lembaga Pendidikan Tenaga Kependidikan.

Degeng, I. N. S. (1990). Desain Pembelajaran: Teori dan Praktek, Proyek Penulisan Buku Teks: PPS IKIP Malang.

(1997). Strategi

Pembelajaran: Mengorganisasi Isi dengan Model Elaborasi. Malang: IKIP Malang dan IPTPI.

DEPDIKNAS, (2008). Panduan Pengembangan Bahan Ajar, Direktorat Pembinaan Sekolah Menengah Atas, Jakarta.

Dick, Walter dan Carey, Lou. (1990). The Sytematic Design of Instruction, Third Edition. Harper Collins.

Dick, Walter, Carey, Lou \& James O. Carey. (2001). The Systematic Design of Instruction, $5^{\text {th }}$ edition. New York: Addison-Wesley, Longman.

Hamalik, Oemar. (1994). Media Pendidikan, Bandung: PT. Citra Aditya Bakti.

Hakim, Ramalis. (2001). Pengembangan Paket pembelajaran Matakuliah Senirupa pada Jurusan Pendidikan Senirupa. Tesis tidak diterbitkan., Malang: PPS TEP UM.

Heinich, R Molenda., M Russel, J.D \& Smaldino. 2002. Instructional Media and Technologies for Learning, Upper Saddle River, NJ: Pearson Education.

Ibrahim, H, Sihkabuden, Suprijanta, \& Kustiawan, U. (2001). Media Pembelajaran: Bahan Sajian Program Pendidikan Akta Mengajar. Malang: FIP. UM.
Izzuddin, Muhammad. (2009). Memperbaiki Bacaan Al-Qur'an Metode Tartil 12 Jam, Solo: AsSalam.

Januszewski, Alan \& Molenda, M. (2007). Educational Technology, London: Lawrence Erlbaum Associates.

Kementerian Pendidikan Naional Universitas Negeri Malang. (2010). Pedoman Penulisan Karya Ilmiah. Malang: Universitan Negeri Malang.

Mbulu, Joseph \& Suhartono. 2004. Pengembangan Bahan Ajar, Malang: Elang Mas.

Miarso, Yusufhadi. (1987). Penelitian Instructional, Survey Model Pengembangan Instructional. Jakarta: Depdikbud Dirjen Dikti.

Munir, Misbahul. (2005). Ilmu \& Seni Qiro'atil Qur'an Pedoman bagi Qori-Qori'ah Hafidh-Hafidhoh dan Hakim dalam MTQ. Semarang: Binawan.

Mustikasari, Ardiani. (2008). Mengenal Media Pembelajaran, Makalah., www.edu-articles.com.

Percival, F \& Ellington, H. (1988). Teknologi Pendidikan, Terjemahan Sudjarwo, S. Jakarta: Erlangga.

Rooijakkers, Ad. (1989). Mengajar dengan Sukses, Jakarta: PT Gramedia.

Sadiman, A.S., Rahardjo, R., Haryono, A., \& Rahadjito. (1990). Media Pendidikan: pengertian, pengembangan dan pemanfaatannya, Jakarta: CV. Rajawali.

Santyasa, I Wayan. (2007). Landasan Konseptual Media Pembelajaran, Makalah, Klungkung: Universitas Pendidikan Ganesha.

Seel, Barbara B. \& Rita C. Richey. (1994). Instructional Technology: The Definition and Domains of The Field. Washington. Association for Educational 
Communications and Technology (AECT).

(1994). Instructional

Technology: The Definition and

Domains of The Field. Terjemahan

Dewi S Prawiradilaga, R.

Rahardjo, Yusufhadi Miarso.

Jakarta: IPTPI \& LPTK.

Setyosari, Punaji. (2001). Rancangan Pembelajaran; teori dan Praktek. Malang: Penerbit Elang Mas.

Sudarma, I Komang, (2006). Pengembangan paket pembelajaran dengan model Dick \& Carey Mata Kuliah Pengembangan Media Pendidikan II Program S1 Teknologi Pendidikan IKIP Negeri Singaraja. Tesis tidak diterbitkan., Malang: PPS TEP UM.

Sudjana, Nana. \& Rivai, Ahmad. 1992. Media Pengajaran. Bandung: CV. Sinar Baru Algensindo.

Suliha, Siti. 2008. Pengembangan paket pembelajaran matakuliah pengembangan kurikulum pendidikan agama islam untuk mahasiswa STAI Al-Hamidiyah Bangkalan. Tesis tidak diterbitkan., Malang: PPS TEP UM.

Suparman, M. Atwi \& Aminuddin Zuhairi. 2004. Pendidikan Jarak Jauh Teori dan Praktek, Jakarta: Universitas Terbuka.

Sutopo, Ariesto Hadi. 2003. Multimedia Interaktif Dengan Flash. Yogyakarta: Graha Ilmu.

Syahid, Ahmad. 2003. Pengembangan Bahan Ajar Matakuliah Rancangan Pembelajaran dengan Menerapkan Model Elaborasi. Tesis tidak diterbitkan., Malang: PPS TEP UM.

Wahana Komputer. 2007. Seri Buku Pintar: Menjadi Seorang Desainer Grafis. Semarang: Penerbit Andi.
Wahyudi, Moh. 2005. Ilmu Tajwid Plus Edisi Terlengkap. Surabaya: Halim Jaya.

Wahyudi, Moh. 2007. Ilmu Tajwid Plus Edisi Terlengkap. Edisi Revisi. Surabaya: Halim Jaya

Warsita, Bambang. 2008. Teknologi Pembelajaran: Landasan \& Aplikasinya. Jakarta: PT. Rineka Cipta.

Yurni, Irma. 2009. Pengembangan paket pembelajaran matakuliah pendidikan kewarganegaraan dengan model Dick \& Carey pada Universitas Malikussaleh Lhokseumawe Nanggroe Aceh Darussalam. Tesis tidak diterbitkan., Malang: PPS TEP UM.

Zulkarnaini. 2009, Pembelajaran dengan bahan Ajar Buatan Guru, Makalah, Padang: Universitas Negeri Padang. 